Canisius College USA

Royal Academician (SKANU Belgrade)

Distinguished Visiting Professor \& Editor

(permanent status),

Faculty of Philology, University of Belgrade

\title{
ON NATIONAL IDENTITY: AN EVOLUTIONARY PERSPECTIVE
}

\begin{abstract}
Summary
The concept of identity is a very problematic theme when considered within our modern worldview, which is grounded in both a cosmic perspective and an evolutionary framework. For a serious thinker, there is no lasting or fixed or permanent entity in the flux of reality; all objects and events and relationships are temporary. Pervasive change even includes nations. Of course, a dynamic interpretation of nature in both science and philosophy extends to the human species in general, and to each past and future society in particular. Nations are not excluded from change and evolution, or from extinction. Anthropology recognizes the emergence of our species from a long sequence of previous hominid forms: remote fossil apes, protohumans, fossils humans, humans [from Homo habilis through Homo erectus to Homo sapiens], and even the possibility of transhumans and posthumans in the distant future. Our success has been largely due to a changing identity: the emergence of sustained bipedality, the use of ingenious technology, and the development of symbolic language as articulate speech, as well as living in ever-more larger and ever-more complex groups.

Anthropologists distinguish among different stages of socio-culture development: bands, tribes, chiefdoms, states, and empires. Humans are now experiencing a transitional stage: modern civilization is undergoing both planetary convergence and cosmic divergence at the same time. Consequently, globalization and modernization are rapidly altering the identity of nations, and even our own species will change at an accelerating rate, especially with the utilization of both nanotechnology and bioengineering. The global Internet is now uniting distinct (but not separate) nations, while ongoing advances in science and technology are preparing our human species for its venture away from the earth and into outer space, e.g., the exploration of and probable habitation on the so-called red planet Mars. Within the intellectual footsteps of Charles Darwin and Herbert Spencer (among others), one may envision the emergence of a collective
\end{abstract}


humankind as envisioned by the Jesuit mystic Pierre Teilhard de Chardin, or the ultimate value of superior individuals as was stressed by the philosopher Friedrich Nietzsche. No doubt, if our species survives, the concept of a human nation will be radically different in the centuries yet to come from what it is today.

Key words: Anthropology, Convergence, Divergence, Evolution, Future, Language, Materialism, Science, Technology, Worldview

As a result of the pivotal writings of Charles Darwin (1808-1882), the first anthropologists were eager to extend the factual theory of organic evolution from biology to the social sciences. They maintained that the framework of evolution would account for the origin and history of all those socio-cultural aspects of our species; these elements range from the arts and political structures to religious beliefs and kinship systems, as well as languages and technologies. For lack of sufficient empirical evidence, ethnologists and culturologists used the comparative method; they held that the thoughts and actions of present hunting/gathering societies now eking out an existence on the earth are, in general, analogous to those thoughts and actions of early hominids living in nomadic bands on the extensive savannahs of Africa during the Villafranchian time.

Among early social theorists, the German philosopher Karl Marx (1818-1883) had been greatly influenced by those major ideas of Hegel and Feuerbach; he later found inspiration in the evolutionary perspective advocated in the scientific writings of Charles Darwin. In fact, in his focus on our own species, Marx saw his dynamic social framework as an extension of Darwin's evolutionary biological framework. Marx himself advocated a conflict theory that stressed the alienation and exploitation pervasive throughout the emerging industrialized nations. He envisioned that, through both enlightened awareness and social action, the proletariat class would eventually bring about an inevitable revolution followed by the establishment of global communism (as he saw it). In the future, according to Marx's vision, a united humankind would enjoy ongoing fulfillment within an ideal collective society without the following aspects: classes, capital, religion, state government, monogamy, private property, and the profit motive. In short, the age of separate nations would end! Of 
course, all political ideologies and social systems have their advantages and disadvantages: who would really choose to live in Plato's alleged ideal republic or Marx's alleged perfect society? If humankind continues to survive, then one can only speculate on what its socio-political milieu will be like hundreds or thousands of years from now. No doubt, nations as they do exist today will become a thing of the past.

Karl Marx taught that human history progresses through struggle and opposition; reminiscent of Hegel's dialectical orientation, Marx taught that qualitative changes occur in revolutionary leaps (contrast with the quantitative changes that occur as a result of gradual development). For him, the identity of specific nations would give way to both a collective society and the brotherhood of humankind on a planetary scale. Whether one endorses revolution or evolution, it remains a fact that few social theories have had such a profound and lasting influence on actual humans in the concrete world as has atheistic dialectical social Marxism.

Not surprising, within his evolutionary framework of 1876, Friedrich Engels (1820-1895) stressed the pervasive role that labor, e.g., the use of implements, has played in the transition from apes to humans. In his own viewpoint grounded in dialectical materialism, he saw four characteristics as being essential to the emergence of our successful species: a complex brain, the use of language, collective social behavior, and the opposable thumb. For Engels, the human being is a product of, dependent upon, and totally within the evolution of material nature. Within social evolution, tribes developed into states and nations. Like Marx, Engels envisioned the formation of a global society as an inevitable result of the movement from capitalism to communism.

Herbert Spencer (1820-1903) advocated cosmic evolution, an organismic view of human society, and the "survival of the fittest" as a social principle. Spencerian thought held to the progressive socio-cultural evolution of humankind as a result of the inheritance of biological, intellectual, social, and moral traits; as such, this comprehensive view went far beyond the biological focus of Lamarckism. Consequently, Spencer's Social Darwinism is grounded in a ruthless development of human groups that favors privileged individuals over a society in general. Concerning religious beliefs, Spencer was an agnostic who maintained that the con- 
cept of a human soul had its origin in primitive humans failing to correctly understand and appreciate dreams. However, Spencer saw a limit to the evolutionary progress of a nation, with social evolution followed by social devolution (just as organic evolution will be followed by organic devolution). Yet, his human perspective remained a planetary one, although his cosmic perspective offered a comprehensive view of the place of our species with this evolving and devolving universe.

Sir Edward Burnett Tylor (1832-1917), the father of cultural anthropology, authored Primitive Culture (1871) and Anthropology (1881). He was primarily concerned with the problems of early religion and held that the human being misinterpreted the cause-and-effect relationships in his beliefs and rituals. For Tylor, religion is the belief in the existence of spiritual beings; as such, the central theme of primitive religion is the concept of animism. Tylor taught that the origin of animism resided in a misunderstanding of life, death, hallucinations, and especially dreams (this misunderstanding resulted in a duality between matter and soul, which in turn gave rise to the belief in an immortal human soul). Furthermore, he advocated the following evolutionary sequence: totemism, then polytheism, and finally monotheism. He saw that cultural evolution manifests a decreasing reliance on magic and religion as a direct result of the increasing success of science and technology (essentially, there is an ongoing evolutionary movement from the irrational to the rational), perhaps resulting in the eventual demise of both magic and religion in the distant future. Finally, he saw socio-cultural evolution passing through three major stages: from savagery, through barbarism, to civilization; of course, there are numerous minor levels of development within each of these three major stages of socio-cultural evolution.

In summary, Tylor held to the following positions: (1) the unilinear, predetermined, and progressive evolution of society and culture; (2) the socio-cultural evolution of explanations from magico-religious beliefs to scientific understanding and rational appreciation; (3) the parallel invention of cultural traits resulting in similar specific evolutionary histories; (4) the simple diffusion of cultural traits through social contacts; (5) the interpretation of contemporary so-called primitive societies as "living fossils"; (5) the existence of "survivals" in present-day cultures; and (7) the 
psychic unity of humankind. Tylor's major contribution in the history of anthropology is a general evolutionary framework within which complex socio-cultural aspects may be both understood and appreciated in terms of change and history. Even so, did not envision the future convergence of distinct nations into a global socio-cultural entity.

Leslie A. White (1900-1975) is the most important exponent of cultural evolution in modern anthropology. He revived the evolutionary framework in the middle of the last century, which had fallen out of favor during the earlier decades. His major work is The Evolution of Culture (1959), which was appropriately published in the very year that celebrated the centennial appearance of Charles Darwin's major work, On the Origin of Species (1859). White's book is very significant, since it reinstated the evolutionary perspective into ethnology; for him, the theory of evolution is as relevant to culturology as it is to biology. For White, the human being is unique because it symbolizes and has culture. In light of more recent discoveries in anthropology, it may now be held that human uniqueness is one of degree, not one of kind, since the great apes use symbols and have a culture; although our species far surpasses the great apes in both its symbolic communications and its technological advancements. Of course, for a proper perspective on things, one should remember that no great ape could ever give a presentation on Charles Darwin and organic evolution!

For White, culture may be divided into four basic categories: the philosophical or ideological, sociological, sentimental or attitudinal, and technological aspects. He held that culture is extra-somatic or superorganic, i.e., the super-organic is a single system that is non-biological in character, but it is essentially grounded in the biology of the human being. $\mathrm{He}$ also distinguished between human culture in general and a specific culture in particular. Most important, White argued that technology is the basis and determinant of cultural systems; in his viewpoint, as technological control increases, the belief in supernaturalism decreases.

White's view represents an organismic theory of culture. Each specific culture is a unity of interrelated aspects in a moving equilibrium of sequential forms. In general, cultural evolution is held to be non-repetitive and irreversible. Like the evolution of life, the development of culture 
is presented as an energy-harnessing process, antithetical to the second law of thermodynamics. Clearly, White gives preference to technological development in his depiction of cultural evolution within a strictly materialist framework. Each ongoing stage of cultural evolution has more energy at its disposal; each ongoing stage represents an increase in complexity, solidarity, and technological dependence. Within this dynamic framework, the human being is essentially the symboling animal. It is this unique ability to create and use symbols that distinguishes, but does not separate, our species from the great apes or pongids. Humans have the ability to conceptualize and to experiment. Essentially, the symbol is the universe of humanity! Of course, this advantage in the human being is due to the fact that our species has a superior central nervous system and a complex brain (especially significant has been the evolution of our human cerebrum). The outcome of socio-cultural evolution would seem to be a planetary society with a global culture. In such a convergence, specific nations would eventually vanish.

Following the long Stone Age, our Space Age represents a striking if not alarming continuation of tool-making and tool-use and toolownership. However, it must be remembered that a primitive technology does not necessarily imply that all the other aspects of a society are also simplistic. In fact, an alleged primitive society in terms of technology may exhibit a complex language, a complex kinship system, and a complex magico-religious worldview. Human groups have passed from small nomadic bands, through tribes and chiefdoms and states, to expansive sedentary empires. Nations are now united by means of the global Internet, and it may be argued that English has become the planetary language.

One may safely assume that the origin and evolution of culture was the result of the human animal being able to use and then make stone implements before acquiring both a cranial capacity within the modern range and the use of symbolic language as articulate speech. These stone implements may be used as tools or weapons or artworks. Also important was the ability of early humans to group together in ever-larger social units; for ground-dwelling hominids, there was safety in number. Early humans used bone, teeth, horn, claws, wood, and some perishable 
materials to defend themselves against predators, especially during their movement from the diminishing tropical rain-forests to those expanding open woodlands and grassy savannahs. In 1957, anthropologist Raymond A. Dart referred to these material objects as representing the first human culture that emerged over one million years ago, i.e., the Osteodontokeratic culture of the Australopithecines in South Africa (an idea that is still controversial, as was his 1953 idea that the early humans were "killer apes"). During most of human evolution, our species lived in small nomadic groups with a Paleolithic culture. The emergence of nations and metallurgy is a very recent phenomenon in socio-cultural evolution.

In general, following fossil apes and then protohumans, and after several million years of human evolution (represented by Homo habilis and then Homo erectus), the emergence of Homo sapiens was a sudden event. Within this sweeping view, the urbanization of our species was instantaneous and revolutionary, indeed! Like species in organic evolution, civilizations have appeared only to disappear centuries later. At this time in human evolution, one may envision the emergence of a global city. However, two crucial movements are emerging together: planetary convergence and cosmic divergence, i.e., nations are merging while our species is now planning for human migrations to other planets and perhaps even to those distant stars that fascinated our ancestors of the remote past. Now dominating the earth, our species is preparing to leave it. It remains to be seen whether the human being can continue to be successful in its own created environment on this planet, as well as in created environments on worlds elsewhere among those abysses of deep space that call to it.

What will become of our embryonic species thousands or millions of years from now? As with societies and cultures, human extinction remains a possibility. What will become of nations? As envisioned by the Jesuit mystic Pierre Teilhard de Chardin, is humankind heading toward a distant collectivism on the earth? Teilhard referred to the emergence of a planetary Omega Point as the final end-goal of a converging and involuting humankind on the earth. How far might human enhancement take our species? As envisioned by the philosopher Friedrich Nietzsche, is the future value of humankind to be found only in its superior creative indi- 
viduals?

Nietzsche saw our species as a temporary link between the fossil apes of the remote past and the overbeings to emerge in the distant future. Will the ongoing convergence of nanotechnology and bioengineering result in the emergence of a society of transhumans as Homo futurensis, a form as different from our species as Homo sapiens of today is different from Homo erectus of the remote past. It must be noted that neither Nietzsche nor Teilhard envisioned the human animal leaving planet earth in order to exist elsewhere in this cosmos.

From the cosmic vision of Giordano Bruno (1548-1600) in the Italian Renaissance to the writings of Marvin Farber (1901-1980) in the recent past, our species now sees itself as being merely a fleeting fragment of a material universe that seems to be eternal in time, infinite in space, and endlessly changing. Going beyond nations, Bruno saw himself as a citizen of this universe. With blunt frankness, Farber referred to a human being as a "bag of bones" when considering the insignificance of our species within a cosmic framework. And yet, despite the unimaginable vastness of this universe, the human being is able to grasp (although incompletely) the size and age of this cosmos. Furthermore, science and technology transcend languages and nations. One may expect that human wisdom will guide the future of our species both on this planet and throughout the cosmos.

What is the shape of things to come? Of course, if transhumans also evolve, then one cannot imagine the nature of posthumans. In what social groups will such beings exist? How will they communicate among themselves? What will they value? I refer to such an entity as a cosmic-overbeing. No doubt, the concept of a nation will have long been lost to new concepts beyond our present comprehension. It quickly becomes obvious that a serious consideration of evolution has far-reaching ramifications for our human species. In fact, as already suggested, the identity of our own species will be surpassed as time and change alter the nature of all things.

\section{Acknowledgements:}

I am very grateful to the following friends and colleagues for their 
help and/or inspiration during the preparation of this academic essay: Distinguished Professor Dr. Marvin Farber, Pamela Rae Huteson, Dr. David Alexander Lukaszek, Professor Dr. Ljiljana Markovic, Branko Milicevic, Alexander V. Tenodi, Ryan J. Trubits, and Shrikant Vardhan.

\section{Selected References:}

Bickerton, Derek. Adam's Tongue: How Human's Made Language, How Language Made Humans. New York, Hill and Wang, 2009.

Birx, H. James. Darwin, Charles. In: Birx, H. James (Ed.). Encyclopedia of Time: Science, Philosophy, Theology, \& Culture. 3 Vols. Thousand Oaks, SAGE Publications, 2009, Vol. 2, pp. 916-919.

Birx, H. James. Evolution: As I See It. In: Anthropologia Integra, 1(2): 7-10, 2010.

Birx, H. James. Evolution: Science, Anthropology, and Philosophy. In: Birx, H. James (Ed.). 21st Century Anthropology: A Reference Handbook. Thousand Oaks, SAGE Publications, 2010, Vol. 2, pp. 586-599.

Birx, H. James. Human Evolution. Springfield, Charles C Thomas, 1988, esp. pp. 221-233.

Birx, H. James. Identity \& Evolution: Prehumans, Humans, Transhumans, Posthumans. In:

Humanism: Culture or Illusion. Belgrade, University of Belgrade/Faculty of Philology, 2015, Vol. 1, pp. 177-200.

Birx, H. James. Interpreting Evolution: Darwin, Nietzsche, \& Teilhard de Chardin. In: The Journal of International Civilization Studies, 1(2): 22-46, Winter 2016.

Birx, H. James. Pierre Teilhard de Chardin: Critical Reflections. In: Anthropologia Integra, 6(1): 7-22, 2015.

Birx, H. James. Theories of Evolution. Springfield, Charles C Thomas, 1984.

Birx, H. James, ed. Encyclopedia of Anthropology. 5 Vols. Thousand Oaks, SAGE Publications, 2006. Refer to relevant entries.

Bruno, Giordano. On the Infinite, the Universe, and the Worlds. CreateSpace/Huginn, Munnin, 2014. Original work published in London 1584.

Burling, Robbins. The Talking Ape: How Language Evolved. Oxford, Oxford University Press, 2005.

Childe, V. Gordon. Social Evolution. New York, Meridian, 1951.

Dart, Raymond A. The Osteodontokeratic Culture of Australopithecus prometheus. Transvaal Museum Memoir, No. 10, 1957.

Dart, Raymond A. The Predatory Transition from Ape to Man. International Anthropological and Linguistic Review, 1: 201-219, 1953.

Darwin, Charles. On the Origin of Species by Means of Natural Selection: Or, the Preservation of Favored Races in the Struggle of Life. Amherst, Prometheus Books, 1991. Original work published 1859. 
Darwin, Charles. The Autobiography of Charles Darwin: 1808-1882. Barlow, Nora (Ed.). New York, W.W. Norton, 1969. Original work published 1887, unexpurgated edition published 1958.

Darwin, Charles. The Descent of Man and Selection in Relation to Sex. Amherst, Prometheus Books, 1998. Refer to the Introduction by H. James Birx, pp. ix-xxvii. Original work published 1871.

Darwin, Charles. The Voyage of the Beagle. Amherst, Prometheus Books, 2000, esp. pp. 394-424, 523. Refer to the Introduction by H. James Birx, pp. vii-xxii. Original work published 1839.

Dewey, John. The Influence of Darwin on Philosophy, and Other Essays in Contemporary Thought. Bloomington, Indiana University Press, 1965, esp. pp. 1-19.

Engels, Friedrich. The Part Player by Labor in the Transition from Ape to Man. New York, International Publishers, 1950. Written but uncompleted 1876, published in German 1895-1896, in English 1934.

Farber, Marvin. Basic Issues in Philosophy: Experience, Reality, and Human Values. New York, Harper Torchbooks, 1968, esp. pp. 219-222.

Farber, Marvin. Naturalism and Subjectivism. Albany, State University of New York Press, 1968.

Geertz, Clifford. The Interpretation of Cultures: Selected Essays. New York, Basic Books, 1973.

Haeckel, Ernst. Last Words on Evolution: A Popular Retrospect and Summary. New York, Peter Eckler, 2007. Lectures delivered in Berlin, April 1905.

Harris, Marvin. Cultural Materialism: The Struggle for a Science of Culture. New York, Vintage Books, 1980.

Harris, Marvin. The Rise of Anthropological Theory: A History of Theories of Culture. New York, Thomas Y. Crowell, 1970, esp. pp. 142-249.

Hegel, Georg Wilhelm Friedrich. The Phenomenology of Spirit. CreateSpace, 2016. Original work published in Germany 1807.

Kurtzweil, Ray. The Singularity Is Near: When Humans Transcend Biology. New York, Penguin Books, 2005.

Leakey, Richard E.F. The Origin of Humankind. New York, HarperCollins/Basic Books, 1994.

Mayr, Ernst. What Evolution Is. New York, Basic Books, 2002.

Milicevic, Branko. Humans in the Cosmos! In: Birx, H. James (Ed.). Nietzsche \& 2001: A Space Odyssey. Belgrade, University Library/University of Belgrade, 2012, pp. 42-43.

Nietzsche, Friedrich. Thus Spake Zarathustra. Birx, H. James (Ed.). Amherst, Prometheus Books, 1993. Refer to the Introduction by H. James Birx, pp. 13-27. Original work written 1883-1885.

Rachels, James. Created From Animals: The Moral Implications of Darwinism. Oxford, Oxford University Press, 1999. Original work published 1990.

Sahlins, Marshall D. \& Elman R. Service, eds. Evolution and Culture. Ann Arbor, University of Michigan Press, 1961. 
Teilhard de Chardin, Pierre. The Phenomenon of Man. rev. ed. New York, Perennial/ HarperCollins, 2008. Refer to 1958 Introduction by Sir Julian S. Huxley. Original work written in China 1938-1940, published in France 1955.

Tenodi, Alexander V. Epilogue: On Emerging Conflicts. In: Birx, H. James (Ed.). Frankenstein: Critical Reflections. Belgrade/University of Belgrade/Faculty of Philology, Belpak, 2018. pp. 164-215.

Tylor, Sir Edward Burnett. Primitive Culture. 2 Vols. New York, Harper Torchbooks, 1958. Warofsky, Marx. Feuerbach. Cambridge, Cambridge University Press, 1977.

White, Leslie A. The Evolution of Culture: The Development of Civilization to the Fall of Rome. New York, McGraw-Hill, 1959.

Whitehead, Alfred North. Science and the Modern World. New York, Free Press, 1967. Original work published 1925.

Wilson, Edward O. The Social Conquest of Earth. New York, W.W. Norton, 2013.

\section{Х. Џејмс Биркс}

\section{О НАЦИОНАЛНОМ ИДЕНТИТЕТУ: ЕВОЛУЦИОНА ПЕРСПЕКТИВА}

\section{Сажерак}

Концепт идентитета је веома проблематична тема када се разматра унутар нашегсавременог поглед на свет, који се темељи и на космичкој перспективи и на еволуционом окружењу. За озбиљног мисллиоца, не постоји трајни или устаљен или стални ентитет у оном флуксу реалности; сви објекти и догађаји и односи су привремени. Свеобухватна промена укључује и нације. Наравно, динамичко тумачење природе и у науци и филозофији се простире на људску врсту уопште и на свако прошло и будуће друштво. Нације нису искључене од промена и еволуције, нити од изумирања.

Наш успех је у великој мери резултат промњнљивог идентитета: појављивања трајне двосмислености, коришћења генијалних технологија и развоја симболичког језика као артикулираног говора, као и живљења у све већим и све сложенијим групама. Људи сада доживљавају прелазну фазу: савремена цивилизација у исто време пролази кроз планетарну конвергенцију и космичку дивергенцију. Сходно томе, глобализација и модернизација брзо мењају идентитет нација, а чак и наше сопствене врсте ће се променити убрзано, посебно уз коришћење и нанотехнологије и биоинжењеринга посебно коришћењем нанотехнологије и биоинжењеринга. 
Глобални Интернет сада обједињује различите (али не одвојене) нације, док је у току напредак у науци и технологији, који припрема нашу људску врсту за свој подухват далеко од земље и у свемир, нпр. истраживање и вероватно становање на тзв. црвеној планети Марс.

У оквиру интелектуалних корака Чарлса Дарвина и Херберта Спенсера (између осталог) може се предвидети настанак колективног човечанства. Без сумње, ако наша врста преживи, концепт људског народа ће се радикално разликовати у вековима који тек долазе.

Кључне речи: антропологија, конвергенција, дивергенција, еволуција, будућност, језик, материјализам, наука, технологија, поглед на свет 